UDC 65.015.3: 330.526.5

JEL Classification: M3, Q001

Garkusha V.V., Zhuravel V.V., Dotsenko A.E., Sliuta A.O.

\title{
BUSINESS COMPETITIVENESS AS CONSTITUTING ITS STRATEGIC DEVELOPMENT
}

\author{
Ukrainian State University of Chemical Technology, Dnipro, Ukraine
}

\begin{abstract}
In article methodical approaches to determination of a strategic development of the entity are researched. It is determined that three approaches to competition determination usually allocate: the first approach determines the competition by the main criterion in type definition of the industry market (the theory about structure of the market); the second approach determines the competition as competitiveness in the market; the third approach considers the competition an equilibrium element of the demand and supply in a market mechanism. Approaches to determination of a strategic development of the entity are analysed. It is established that the main sign of competitiveness of a producer is his competitive line item and competitive advantages concerning other subjects. It is offered to consider business competitiveness of one of important components of a strategic development. Depending on effective objectives, strategy determines methods of achievement of competitive advantages, behavior of the company in competitive struggle, the general direction of development, etc. Therefore, business competitiveness is an important component of a strategic development and requires further studying. Assessment of competitiveness is performed for the purpose of determination of potential opportunities of the entity and measures of ensuring high level of long-term competitive advantages which will answer strategic objectives of the entity.
\end{abstract}

Keywords: strategic development of the entity, management of development, competitive advantages, competitive line item, classification of development strategies.

DOI: $10.32434 / 2415-3974-2018-8-2-73-78$

\section{Problem statement}

Modern integration processes of transformation of economy of Ukraine induce to use of modern enterprise management methods. One of the main management tools development of the entity is the methodology of strategic management. Activities for strategic management are aimed at providing a strong strategic line item which provides long corporate sustainability in unstable conditions.

The leading role in the solution of strategic tasks of the entity is played by strategic planning which shall contain development and support of strategic balance between the purposes and opportunities of the entity in market conditions $[3,6]$.

Practical experience demonstrates that the organizations which perform comprehensive strategic planning of the activities work more effectively and get profit much above, than average on an industry.

\section{Analysis of researches and publications}

The famous American scientist M. Porter devoted to problems of strategy of advancing of competitors the works. He studied a question of competitive advantages of the countries and the companies, competitive potential and a competitive environment. The following steps of studying of the competition came scientists M. Tracey, F. Virsema, J.F. Moore, etc. which considered the directions of forming of strategy of competitive struggle and processed the theory of achievement of a market leadership. The competition as dynamic process which constantly changes influences of various factors was researched by I. Kirtsner. Gaining future markets in competitive struggle was the leading link in scientific works G. Hammel and K.K. Prakhalad. Problems of competitiveness and competitive strategy were researched in works of such specialists as M. Dolinskaya, M.I. Knysh, Ж. - Zh. Lamben, N.K. Moiseyeva, R.A. Fatkhutdinov, A.Yu. Yudanov. G.L. Azoyev, Yu.I. Korobov, L.P. Kurakov, L.G. Ramensky and others. On the other hand, it will be reasonable to consider scientific works concerning a research and studying of questions of innovations, potential and development of the entity, its competitiveness of such authors as: Lapin E.V.,

(C) Garkusha V.V., Zhuravel V.V., Dotsenko A.E., Sliuta A.O.., 2018 
Ilyashenko S.M., Zavlin P.M., Willow of VA., Novikova I.V., Solovyov V.P., Fedulova L.I., Fedorenko V., Krasnokutskaya N.V., Hryniv A.V., Smirnova A.A., Titova N.N., Masur Je.P., Smirnov Ya.V., Kosolapov A.V., Girenko-Kotsuba A.A., Martyusheva L.S., Kalyshenko V.A., Mityakova A.I. [11].

Development and transformations of society led to corresponding changes and the concept «strategy» of more and more complicated business conditions. So, A. Chandler, one of original authors of developments in the direction of strategic planning, considered that strategy is a determination of the main long-term goals and tasks of the entity and approval of a rate of actions, the resource allocations necessary for achievement of these purposes [8]. According to M. Porter strategy represents a method of reaction to external opportunities and threats, internal strong and weaknesses [5]. I. Ansoff characterized a concept of strategy as a set of rules for decision making by which the organization is guided in the activities [2]. G. Mintsberg considers strategy as unity $\langle 5 \mathrm{P} »$ : the plan (plan), a sample, model, a template, positioning, prospect and the distracting maneuver. At the same time strategy as the plan is considered as a certain set of rates of the actions created according to a situation [4]. Researchers A. Thompson and A. Strickland considered that strategy is a set of actions and approaches to achievement of the set indicators of activities [7].

The purpose of this work is the research and the analysis of methodical and practical approaches to business competitiveness influence determination as a component in management of its strategic development.

\section{Main material}

The research of the scientific references devoted to a competitiveness perspective allowed to draw a conclusion that scientists allocate usually three approaches to competition determination. The first approach [1] determines the competition as criterion which is the main in type definition of the industry market. This approach is based on the modern theory of morphology of the market (the theory about structure of the market). The second approach determines the competition as competitiveness in the market [2]. Such approach is more widespread among domestic scientists. The third approach considers the competition an element of a market mechanism that results in balance of the demand and supply. Such approach is characteristic of the classical economic theory [3].

The concept «strategy» and her understanding change along with complication of conditions of business. So, A. Chandler, the author of one of the first works in the field of strategic planning, I considered that strategy is a determination of the main long-term goals and tasks of the entity and approval of a rate of the actions, resource allocation necessary for achievement of these purposes [8].

According to M. Porter strategy represents a method of reaction to external opportunities and threats, internal strong and weaknesses [5]. I. Ansoff determines strategy as a set of rules for decision making by which the organization is guided in the activities [2]. G. Mintsberg considers strategy as unity «5P»: content, a sample, model, a template (pattern), positioning (line item), prospect and the distracting maneuver (plus) at the same time, strategy as the plan is considered as a certain set of the directions of the actions created according to a situation [4]. According to A. Thompson and A. Strickland strategy represents a set of actions and approaches to achievement of the set indicators of activities [7].

Thus, it is necessary to understand the master plan of actions determining priorities of strategic tasks, resources and the sequence of actions for achievement of strategic objectives as the strategy of the organization. Therefore the main task of strategy consists in translating the organization from its this condition to a desirable condition in the future.

Depending on the level of acceptable strategic decisions allocate corporate, competitive and functional strategies [6].

Corporate (basic, portfolio) strategy concern the general direction of development the entity or the integrated (corporate) economic system in general.

The main objective of basic strategy is the choice of those reference points and elements of system to which it is necessary to direct appropriate resources and investments and also management tools which will allow to receive the necessary level of efficiency and stability.

The main moments of such strategy cover: resource allocation between divisions on the basis of the portfolio analysis; diversification of production for the purpose of decrease in economic risk and receipt of effect of synergy; change of an organizational structure of corporation; development of single strategic orientation of divisions.

Competitive strategy extend to specific economic divisions of the entity. Their purpose - to provide effective implementation of business plans of development of separate processes, the directions, divisions based on forming of the optimum list of action. Here prospects for possible financing of production are considered. New products, refusal of the existing unpromising products, production, price, advertizing, sales and other strategic initiative in a certain market or a segment of the market reveals.

Functional (business, competitive) strategy are accepted for the benefit of departments and services of the entity. Each functional structure (production, marketing, finance, Research and Development, 
personnel) plans the level of financing and tools of management as a method of achievement of the local purpose of process, function, division. The purpose of data of strategy - identification of competitive line items or effective behavior within the set function.

Modern business, with its fierce competition and periodic shocks, demands from managers of all levels of search of such strategy which guarantees to the entity, on the one hand, the most effective use of resources, on the other hand, the maximum stability of the entity in the conditions of instability of factors of the external environment.

It is possible to allocate two basic strategy, chooses the entity, proceeding from the level of its economic potential, a stage of enterprise lifecycle and an industry and also a line item in the market: - development strategy; - strategy of survival.

The purpose of the development strategy is development and implementation of specific actions in the system of selective destinations on enhancement of financial and economic parameters of the entity with taking into account the existing and potential conditions and restrictions for resources.

In the Fig. 1 types of the development strategy of the company are provided. As economic growth it is possible to allocate the strategy of the concentrated, diversified and integrated growth [3].

The strategy of survival is defensive strategy which is applied in cases of complete disorder of economic activity of the entity, in the condition close to bankruptcy. The purpose of this strategy is stabilization of a situation, further it will be necessary

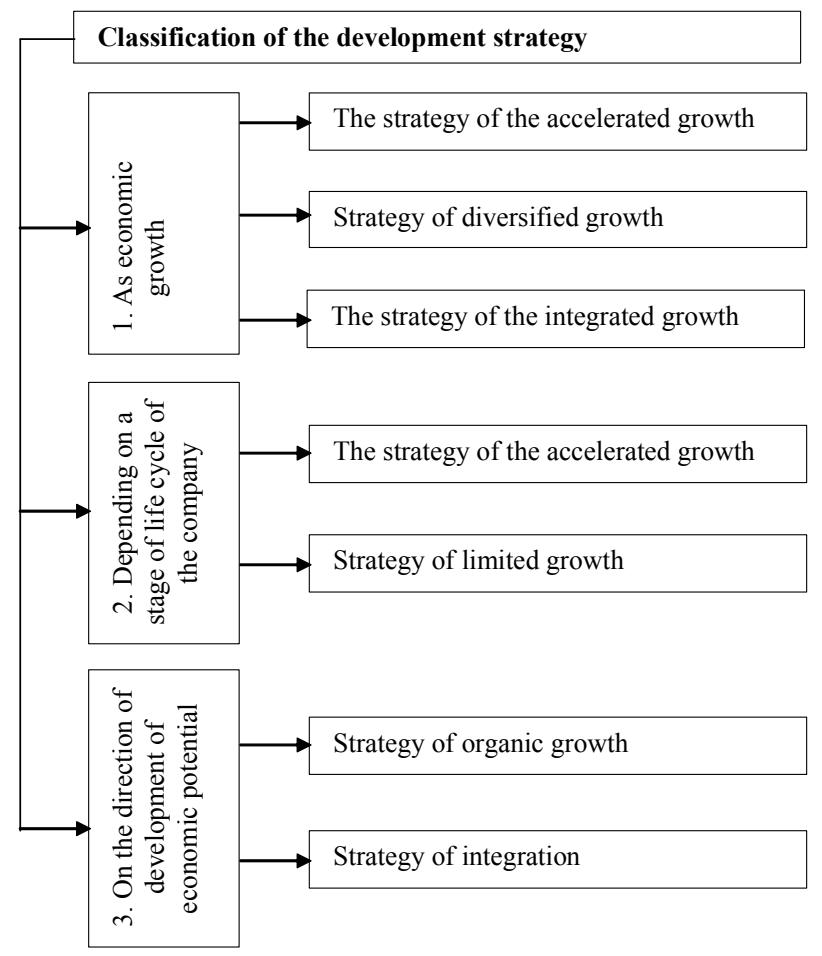

Fig. 1. Classification of development strategies to perform transition from the strategy of stabilization to growth strategy. It is clear, that this strategy can't be long-term.

The business strategy of the entity provides effective functioning of a producer taking into account maintenance of proper level of its competitiveness, characterizing extent of implementation of potential opportunities of the entity on property and content throughout the long period of time of competitive advantage. At the same time the condition of the entity is characterized not only indicators of the current efficiency, but also their dynamics during adaptation of a producer to the changing environmental conditions. The main sign of competitiveness of a producer is his competitive line item and competitive advantages concerning other subjects [9].

Business competitiveness is created of a set of various indicators under the influence of a large number of both external, and internal factors [10].

External factors of influence on business competitiveness are divided into factors of a macro environment and the microenvironment. To a macro environment belong: political and legal, economic, technology, demographic, natural and geographical and sociocultural factors. In world practice the analysis of these factors is called PEST analysis (from an abbreviation of names of basic elements of this Wednesday: - political and legal environment (the political and legal environment) $\mathrm{E}-$ economie environment (economic environment) of $\mathrm{S}-$ sociocultural environment (the sociocultural environment) of $\mathrm{T}$ - technological environment (the technological environment). The microenvironment is provided $\dagger$ by influence of the following factors: a competitive environment (competitors, an industry in which the entity works); buyers (consumers, clients) marketing intermediaries; suppliers: raw materials, materials, energy carriers, labor power, financial resources, equity, information and so forth; labor unions, batches and public organizations, their local authorities; regional authorities (state administration, recommendation, tax administration, treasury, financial body, sanstantion, body of state statistics, fire supervision, technical supervision, etc.).

To the internal environment of the entity, creates its competitiveness, belong: production, finance, personnel and marketing.

Management of business competitiveness happens at three levels: operational, tactical and strategic (Fig. 2).

At the operational level there are processes of management of product competitiveness (goods or service). Tactical level includes forming of competitiveness of trademark and the entity in general. Strategic level covers researches and development of potential of competitiveness. Between indicators of business competitiveness, brand and 


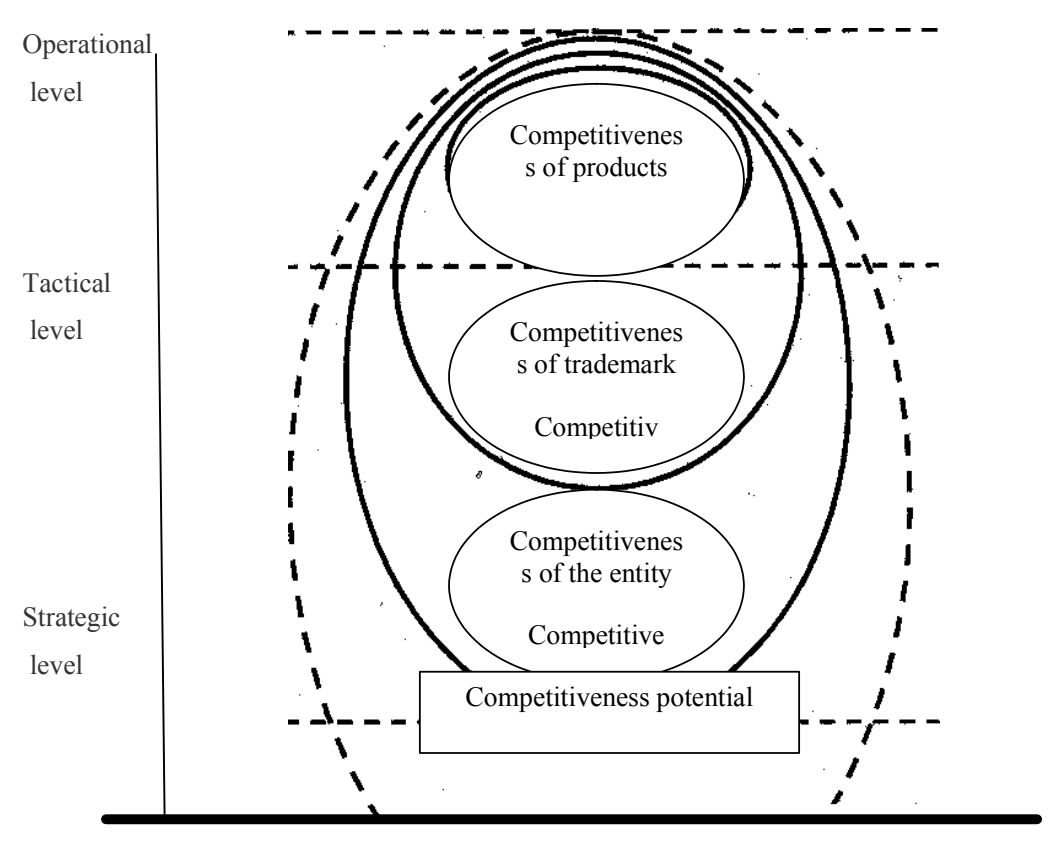

Fig. 2. Structure of business competitiveness [10]

products exist: interrelation and interdependence. It means that product competitiveness and trademark significantly influence a capability of the entity to compete in the market, and the last, $\dagger$ in turn, substantially determines product competitiveness. following:

Distinctions of these categories consist in the

- product competitiveness is determined for each its type, and business competitiveness covers all assortment;

- product competitiveness is determined within rather short period of time, and competitiveness of trademark and the entity - long;

- goods competitiveness is created by functional, rational properties, and competitiveness of brand determines the emotional level of perception by consumers and other subjects of the market;

- level of business competitiveness interests first of all its owner, shareholders and investors for the purpose of determination of feasibility of production in these conditions, and the consumer is interested in products of the entity, its price and quality, image of trademark more.

Production and implementation of competitive products - the compulsory provision of business competitiveness. Business competitiveness - a capability to make and sell competitive products in case of the high service level, to dispose effectively of the available material, labor, financial and information resources in certain markets in a specific period. [12]

More widely systematic work on everything of a production and economic cycle is necessary for providing competitiveness, results in competitive advantages in the sphere of Research and Development, production, management, finance, marketing and so forth. Business competitiveness is result of its competitive advantages on all range of problems of its strategic development (fig. 3).

One of the main directions of forming of competitiveness of industrial enterprise is implementation in activities of the concept of marketing of partnership which essence consists in forming of the long-term relations of a cooperation and trust between subjects of the market for the purpose of receipt of bilateral benefit.

So, competitiveness of the entities represents one of the most important categories of functioning, management and development of the entity which characterizes opportunities and efficiency of adaptation of the entity to conditions of the market environment.

Thus, on the basis of the considered material it is possible to make certain generalization. Without watching variety of approaches to the practical embodiment of strategy of the entity, it is obvious that all of them have something in common that the purpose of any strategy is achievement and deduction of superiority over competitors.

Depending on effective objectives, strategy determines methods of achievement of competitive advantages, behavior of the company in competitive struggle, the general direction of development, etc. Therefore, business competitiveness is an important component of a strategic development and requires further studying. Assessment of competitiveness is performed for the purpose of determination of potential opportunities of the entity and measures of ensuring high level of long-term competitive advantages which will answer strategic objectives of the entity. 
Business competitiveness as constituting its strategic development

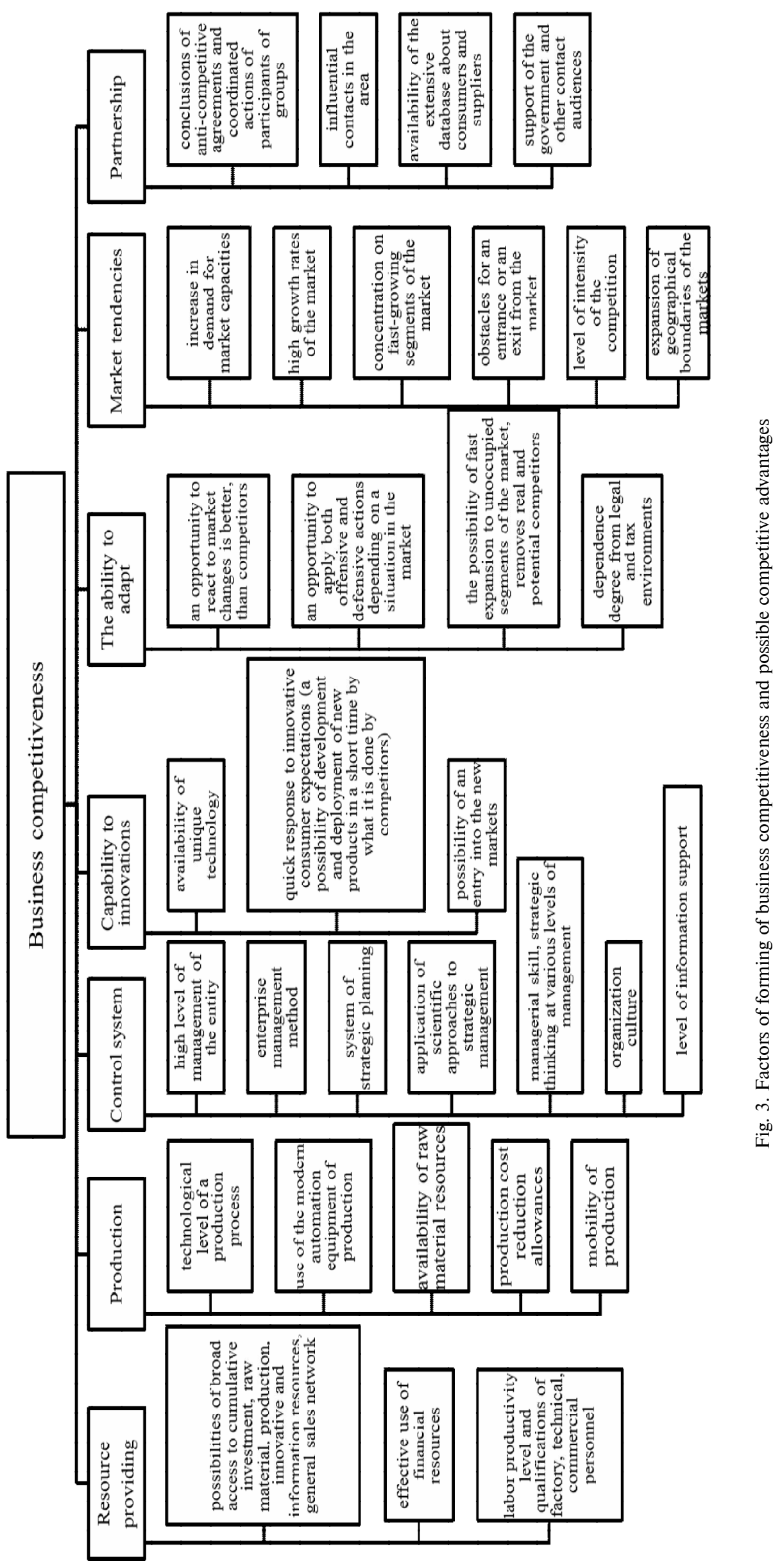




\section{REFERENCES}

1. Akoff R. Planuvannya maybutnoho korporatsiyi. - M .: Syryn, 2002. [Akoff R. Planning of the future of corporation. M.: Sirens, 2002.]

2. Ansoff I. Stratehichne upravlinnya. - M .: Ekonomika, 1989. [Ansoff I. Strategic management. - M.: Economy, 1989.]

3. Vykhanskyy O.S. Stratehichne upravlinnya. - M .: Ekonomist, 2006 [Vikhansky O.S. Strategic management. - M.: Economist, 2006]

4. Myntsberh H.Struktura v kulatsi: stvorennya efektyvnoyi orhanizatsiyi. - SPb .: Piter, 2004. [Mintsberg G. Structure in a fist: creation of the effective organization. - SPb.: St. Petersburg, 2004.]

5. Porter M. Mizhnarodna konkurentsiya: Per. z anhl. / Pod red. V.D.Shchetinina. - M .: Mizhnarodni vidnosyny, 1993. [Malt liquor M. International competition: The lane with English / Under the editorship of V.D. Shchetinin. - M.: International relations, 1993.]

6. Stratehichnyy menedzhment / Za red. Petrova O.M. 2e vydannya. - SPb .: Piter, 2008. [Strategic management / Under the editorship of Petrov A.N. the 2nd edition. - SPb.: St. Petersburg, 2008.]

7. Tompson A. A., Striklend A. Dzh. III. Stratehichnyy menedzhment: kontseptsiyi y sytuatsiyi dlya analizu. - M .: Viloyams, 2007.] [Thompson A. A., Strickland A. Dzh. III. Strategic management: concepts and situations for the analysis. M.: Williams, 2007.]

8. Chandler, Alfred D., Jr. Strategy and Structure: Chapters in the History of the American Industrial Enterprise, 1962.

9. Pavlenko A. F. Marketynh: pidruchnyk / A. F. Pavlenko, A. V. Voychak. - K.: KNEU, 2003. - 246 s. [Pavlenko A. F. Marketing: p_druchnik / A.F. Pavlenko, A.V. Voychak. - To.: KNEU, 2003. - 246 pages.] [in Ukrainian].

10. Knyazik, Yu. M. Vliyaniye of marketing factors on forming of competitiveness of industrial enterprises / Yu.M. Knyazik, T.V. Lebed//the Messenger of the National university «Lviv Polyequipment». - 2011. - the No. 704 Management and an entrepreneurship in Ukraine: stages of formation and problem of development. - Page 44-50.] [in Ukrainian ].

11. Tretyak O.A. Marketynh evolution: stakhes, prioritis, tsontseptual base, tkhe dominatynh lohits//tkhe Russian mahazyne of management [in Russian].

12. Suchasnyy pidkhid do stratehichnoho planuvannya / P. V. Mahdanov // Mystetstvo upravlinnya [Magdanov, P. V. Modern approach to strategic planning / P.V. Magdanov// Management skill - 2011. - No. 1 - S. to 11-27.sky planning / P.V. Magdanov//Management skill]

Received 16.10 .18

Reviewer: Doct of Econ.Sc., prof. Pozhueva T.O.

\section{КОНКУРЕНТОСПРОМОЖНІСТЬ ПІДПРИЕМСТВА ЯК СКЛАДОВА ЙОГО СТРАТЕГІЧНОГО РОЗВИТКУ}

Гаркуша В.В. Журавель В.В., Доценко Г.Е., Слюта А.О.

В статті досліджено методичні підходи до визначення стратегічного розвитку підприємства. Визначено, що зазвичай виділяють три підходи до визначення конкуренції: перший підхід визначає конкуренцію основним критерієм у визначенні типу галузевого ринку (теорія про структуру ринку); другий підхід визначає конкуренцію як змагальність на ринку; третій підхід вважає конкуренцію рівноважним елементом попиту $i$ пропозиції у ринковому механізмі. Проаналізовано підходи до визначення стратегічного розвитку підприємства. З'ясовано, що основною ознакою конкурентоспроможності товаровиробника є його конкурентна позиція та конкурентні переваги відносно інших суб'єктів. Запропоновано вважати конкурентоспроможність підприємства однією з важливих складових стратегічного розвитку. Залежно від ефективних иілей стратегія визначає способи досягнення конкурентних переваг, поведінки компанії в конкурентній боротьбі, загальний напрям розвитку тощо. Отже, конкурентоспроможність бізнесу $\epsilon$ важливою складовою стратегічного розвитку та вимагає подальшого вивчення. Оцінювання конкурентоспроможності здійснюється з метою визначення потенційних можливостей суб'єкта господарювання та заходів забезпечення високого рівня довгострокових конкурентних переваг, які відповідають стратегічним цілям суб'єкта господарювання.

Ключові слова: стратегічний розвиток підприємства, управління розвитком, конкурентні переваги, конкурентна позиція, класифікація стратегій розвитку.

\section{КОНКУРЕНТОСПОСОБНОСТЬ ПРЕДПРИЯТИЯ КАК СОСТАВЛЯЮЩАЯ ЕГО СТРАТЕГИЧЕСКОГО РАЗВИТИЯ}

Гаркуша В.В. , Журавель В.В. , Доценко А.Е. , Слюта А.О.

В статье исследованы методические подходы к определению стратегического развития предприятия. Определено, что обычно выделяют три подхода к определению конкуренции: первый подход определяет конкуренцию основным критерием в определении типа отраслевого рынка (теория о структуре рынка); второй подход определяет конкуренцию как состязательность на рынке; третий подход считает конкуренцию равновесным элементом спроса и предложения в рыночном механизме. Проанализированы подходы к определению стратегического развития предприятия. Установлено, что основным признаком конкурентоспособности товаропроизводителя является его конкурентная позиция и конкурентные преимущества относительно других субъектов. Предложено считать конкурентоспособность предприятия одной из важных составляющих стратегического развития. В зависимости от эффективных целей стратегия определяет способы достижения конкурентных преимуществ, поведения компании в конкурентной борьбе, общее направление развития и тому подобное. Итак, конкурентоспособность бизнеса является важной составляющей стратегического развития и требует дальнейшего изучения. Оиенка конкурентоспособности осуществляется с иелью определения потенциальных возможностей предприятия и мер обеспечения высокого уровня долгосрочных конкурентных преимуществ, которые соответствуют стратегическим иелям предприятия.

Ключевые слова: стратегическое развитие предприятия, управление развитием, конкурентные преимущества, конкурентная позиция, классификация стратегий развития. 